\title{
Three new species of Pseudodactylogyrus (Monogenea: Pseudodactylogyridae) from Australian eels
}

\author{
Kazuo Ogawa ${ }^{1}$, Makoto Iwashita ${ }^{2}$, Craig J. Hayward ${ }^{3}$ and Akira Kurashima ${ }^{4}$ \\ ${ }^{1}$ Meguro Parasitological Museum, Meguro, Tokyo, Japan; \\ ${ }^{2}$ Japan Fisheries Resources Conservation Association, Tokyo, Japan; \\ ${ }^{3}$ National Centre for Marine Conservation and Resource Sustainability, Australian Maritime College, University of Tasmania, \\ Launceston, Tasmania, Australia; \\ ${ }^{4}$ Department of Biological Sciences, Graduate School of Science, The University of Tokyo, Hongo, Bunkyo, Tokyo, Japan
}

\begin{abstract}
Three species of Pseudodactylogyrus Gusev, 1965 (Monogenea: Pseudodactylogyridae) were collected from the gills of Anguilla reinhardtii Steindachner and A. australis Richardson from several localities in Australia and eels imported to Japan from Australia. Pseudodactylogyrus gusevi sp. n. from A. reinhardtii (type host) and A. australis in Queensland, Australia is most similar to P. bini (Kikuchi, 1929), but can be differentiated by the shorter male copulatory tube, heavy sclerotisation of the vaginal tube and the presence of a small projection of the supplementary piece of the hamulus. Pseudodactylogyrus rohdei sp. n. from A. australis (type host) in Queensland, Australia is most similar to P. anguillae (Yin et Sproston, 1948), but differs in the possession of a longer cement gland and the presence of a small projection on the supplementary piece of the hamulus. Pseudodactylogyrus bini sensu Gusev, 1965 and $P$. anguillae sensu Gusev, 1965 are synonymised with $P$. gusevi sp. n. and P. rohdei sp. n., respectively. Pseudodactylogyrus mundayi sp. n. from A. australis, originating in Tasmania, Australia and sent alive to Japan, is most similar to P. kamegaii Iwashita, Hirata et Ogawa, 2002, from which it can be discriminated by the shorter male copulatory tube and the shorter vaginal tube. Dactylogyrus bialatus Wu, Wang et Jian, 1988 from Synechogobius ommaturus (Richardson) (Gobiidae) is transferred to Pseudodactylogyrus as $P$. bialatus comb. n. A phylogenetic tree based on the ITS2 region of six species of Pseudodactylogyrus including P. gusevi and P. mundayi shows that $P$. haze from a goby diverged first, and that species from eels are monophyletic, forming three lineages differing by their zoogeographical distribution. With the three new species and one new combination proposed in this paper, Pseudodactylogyrus is now comprised of eight species infecting anguillid and gobiid fish, and a key to species is presented.
\end{abstract}

Keywords: taxonomy, morphology, phylogeny, ITS2 rDNA, evolution, Anguilla

Monogeneans of the genus Pseudodactylogyrus Gusev, 1965 are gill parasites of fresh and brackish water fishes. Four species have been described: (i) Pseudodactylogyrus bini (Kikuchi, 1929) [syns. Dactylogyrus bini Kikuchi, 1929 and Neodactylogyrus bini (Yin et Sproston, 1948)] from the Japanese eel, Anguilla japonica Temminck et Schlegel, European eel, A. anguilla (Linnaeus), American eel, $A$. rostrata (Lesueur), speckled longfin eel, $A$. reinhardtii Steindachner, giant mottled eel, A. marmorata Quoy et Gaimard, and African longfin eel, A. mossambica (Peters); (ii) Pseudodactylogyrus anguillae (Yin et Sproston, 1948) (syns. N. anguillae Yin et Sproston, 1948 and P. microrchis Ogawa et Egusa, 1976) from A. japonica, $A$. anguilla, $A$. reinhardtii, $A$. marmorata and $A$. mossambica; (iii) Pseudodactylogyrus kamegaii Iwashita, Hirata et Ogawa, 2002 from A. japonica; and (iv) Pseudodactylogyrus haze Ogawa, 1984 from the yellowfin goby, Acan- thogobius flavimanus (Temminck et Schlegel) (Kikushi 1929, Gusev 1965, Ogawa and Egusa 1976, Golovin 1977, Ogawa 1984, Cone and Marcogliese 1995, Hayward et al. 2001, Iwashita et al. 2002, Sasal et al. 2008). In addition, Pseudodactylogyrus pseudobagrus Ling, 1973 was reported on the gills of the yellow catfish Pseudobagrus fulvidraco (Richardson) [= Tachysurus fulvidraco (Richardson)] from China; this species was transferred to Sinidactylogyrus Zhang, 1981 by Zhang (1981).

We had the opportunity to examine parasites of wild Australian eels, A. reinhardtii and A. australis Richardson. We collected specimens comprising three species that all belonged to Pseudodactylogyrus and differed from the known species. Here, we describe these specimens as three new species, and amend the generic diagnosis of Pseudodactylogyrus accordingly. In addition, a new combination is proposed to add another species to the genus.

Address for correspondence: K. Ogawa, Meguro Parasitological Museum, 4-1-1, Shimo-Meguro, Meguro, Tokyo 153-0064, Japan. Phone: +81 3 3716 7244; Fax: +81 33716 7244; E-mail: ogawak@kiseichu.org

ZooBank number for article: urn:1sid:zoobank.org:pub:E3342927-FA7F-41BF-BF28-7B7BB0548CBE 


\section{MATERIALS AND METHODS}

Wild Anguilla reinhardtii from the River Burnett at Bundaberg, Noosa and Redland Bay, Queensland, Australia and A. australis from Noosa, Queensland, Australia were caught commercially and sent to the Zoology Department at the University of New England, Armidale. Wild A. australis, caught commercially in Tasmania and sent to Japan, were also examined. The eels were anesthetised by MS222 or FA100 and the gills were removed. Monogeneans were collected under a stereomicroscope, subsequently flattened and fixed in AFA and stained with Heidenhein's iron haematoxylin, Delafield's haematoxylin or alum carmine for observations of general characters. Specimens fixed in glycerinammonium picrate (GAP), dehydrated and mounted in Canada balsam were used for observations and measurements of sclerotised parts of the parasite. Some of the specimens were compared with the GAP-fixed voucher specimens of $P$. bini collected from A. japonica in Japan and deposited at the Meguro Parasitological Museum, Tokyo (MPM - Collection No. 20997).

Measurements and terminology of sclerotised parts are similar to those of Iwashita et al. (2002), except for the foldable part of the root of the hamulus, which is termed here as the supplementary piece as in Ogawa (1986) (Fig. 1). All figures were drawn using a drawing tube. Measurements, using a calibrated ocular micrometer or digital photo equipment (DS-Fil and DS-L2, Nikon), were given in micrometres as the range and mean and the number of specimens in parentheses. Since the male copulatory tube and sclerotised vaginal tube were irregularly curved, these parts were measured on a computer using the ImageJ program (image processing program available at: http://rsb.info.nih.gov/ $\mathrm{ij} /$ ) as described previously (Ogawa et al. 2012). Fish names follow Froese and Pauly (2015).

To elucidate phylogenetic relationships between two new species and known congeners, the Internal Transcribed Spacer 2 (ITS2) region of five species of Pseudodactylogyrus was sequenced (Table 1); Pseudodactylogyroides apogonis (Yamaguti, 1940) from Apogon semilineatus (Temminck et Schlegel) (Apogonidae) was used as the outgroup. Prior to fixation in $70 \%$ ethanol, worms were identified microscopically by morphological characters of hamuli and/or genital organs. Genomic DNA was extracted from fixed worms using a QIAquick DNA extract kit (QIAGEN, Inc., Valencia, California, USA) following the manufacturer's instructions. The small subunit ribosomal DNA including the ITS regions was amplified using the oligonucleotide primers PD-F (5'-AACCTGGTTGATCCTGCCAG-3') and PD-ITS-R (5'-TAATGCTTAAATTCAGCGGGT-3').

PCR was carried out in $20 \mu \mathrm{l}$ volume containing $0.1 \mu \mathrm{l}$ of Takara EX Taq DNA polymerase (Takara Bio, Inc., Otsu, Japan), $2.0 \mu \mathrm{l}$ of PCR buffer (Takara Bio, Inc.), $1.6 \mu \mathrm{l}$ of dNTP mixture (Takara Bio, Inc.), $1.0 \mu \mathrm{l}$ of $10 \mu \mathrm{M}$ each primers, $2 \mu \mathrm{l}$ of extracted DNA and $12.3 \mu \mathrm{l}$ of distilled water. PCR conditions were as follows: first denaturation at $94^{\circ} \mathrm{C}$ for $5 \mathrm{~min}, 30$ cycles of denaturation at $94^{\circ} \mathrm{C}$ for $30 \mathrm{~s}$, annealing at $50^{\circ} \mathrm{C}$ for $30 \mathrm{~s}$, and extension at $72^{\circ} \mathrm{C}$ for $2 \mathrm{~min}$, and the final extension step at $72{ }^{\circ} \mathrm{C}$ for $2 \mathrm{~min}$. PCR products were checked by running on $1 \%$ agarose gel containing ethidium bromide and purified using a Qiagen DNA purification kit (QIAGEN, Inc.). The cycle sequencing was carried out using BigDye ${ }^{\circledR}$ Terminator v3.1 Cycle Sequencing Kit (Applied Biosystems, Inc., Foster City, USA) with the PD-ITS-R primer and PD-ITS-450F (5'-CGATGAAGAGTGCAGCAAAC-3') as the

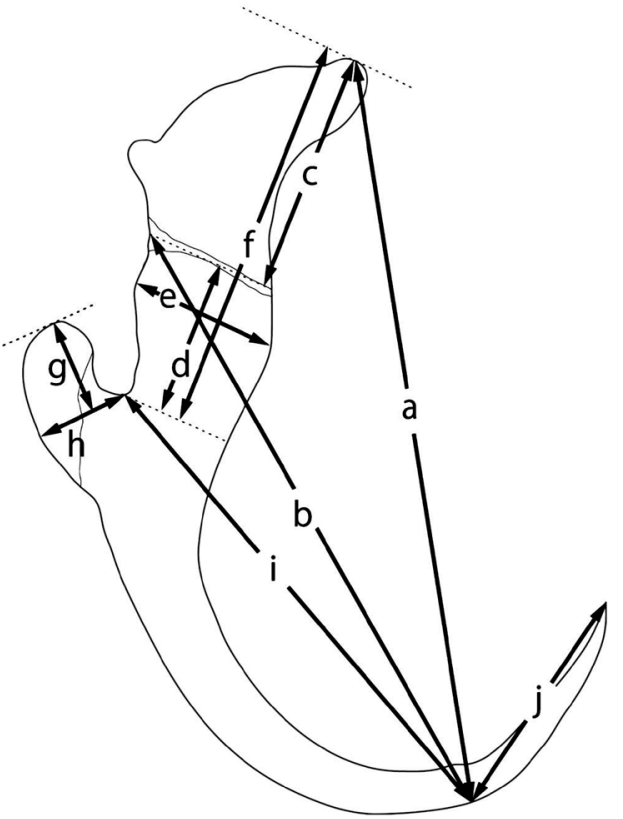

Fig. 1. Measurements and terminology of the sclerotised parts of the hamulus of Pseudodactylogyrus spp. a - length of the hamulus with the supplementary piece; $b$ - length of the hamulus without the supplementary piece; $\mathrm{c}$ - length of the supplementary piece; $d$ - length of the internal process; $\mathrm{e}$ - width of the internal process; $f$ - length of the internal process with supplementary piece; $g$ - length of the external process; $h$ - width of the external process; $\mathrm{i}$ - length of the hamulus base; $\mathrm{j}$ - length of the point.

sequence primer. Sequencing products were purified by Centi-cep columns. Subsequently, products were electrophoresed by an ABI 377 DNA Sequencer (Applied Biosystems, Inc.).

The obtained sequence data were edited by the Genetix Mac 9.0 sequence editor (Software Development Co., Ltd., Tokyo, Japan). Determination of the position of the ITS2 region was carried out by a comparison with the sequence of the Genbank record of the sequence of $P$. bini (Accession No. GQ478293). The multiple alignments of the obtained sequence data were performed using MAFFT v7.215 (Katoh and Standley 2013) with the option L-INS-i. To remove unreliably aligned regions within the datasets, we used Gblocks v0.91b (Castresana 2000) to identify the conserved regions with the following parameter settings: minimum number of sequence for a conserved position: 21 ; minimum number of sequence for a flank position: 34; maximum number of contiguous nonconserved positions: 8; minimum length of a block: 10; allowed gap positions: all. As a result, 438 of 483 positions were used for following phylogenic analysis.

The phylogenic trees were constructed with MEGA6 (Tamura et al. 2013) for maximum likelihood method (ML) and maximum parsimony method (MP). The best-fitting model of evolution selected was Kimura 2-parameter model with invariant sites (K2 + I) by MEGA6. Gaps or missing data were treated using complete deletion option in MEGA6. Bootstrap values were estimated from 1000 replicates and a heuristic search was performed implementing the estimated model parameters using nearest-neighbor-interchange (NNI) branch swapping for ML and Subtree-Pruning-Regrafting (SPR) branch swapping for MP. Evolutionary distance between P. haze and Pseudodactylogyrus spp. of eels and mean 
Table 1. List of specimens of Pseudodactylogyrus spp. used for DNA analysis.

\begin{tabular}{|c|c|c|c|c|}
\hline Species & Host & Locality & No. & Accession No. \\
\hline $\begin{array}{l}\text { Pseudodactylogyrus anguillae } \\
\text { (Yin et Sproston, 1948) }\end{array}$ & $\begin{array}{l}\text { Anguilla japonica } \\
\text { Temminck et Schlegel }\end{array}$ & Yoshida, Shizuoka Pref., Japan & 5 & LC041237-LC041241 \\
\hline P. bini (Kikuchi, 1929) & & Yoshida, Shizuoka Pref., Japan & 5 & LC041242-LC041246 \\
\hline \multirow[t]{4}{*}{ P. gusevi sp. $\mathrm{n}$. } & A. reinhardtii Steindachner & Burnett River, Queensland, Australia & 13 & LC041208-LC041220 \\
\hline & & Noosa, Queensland, Australia & 8 & LC041221-LC041228 \\
\hline & & Redland Bay, Queensland, Australia & 4 & LC041229-LC041232 \\
\hline & & South Brisbane, Queensland, Australia & 1 & LC041233 \\
\hline P. haze Ogawa, 1984 & $\begin{array}{l}\text { Acanthogobius flavimanus } \\
\text { (Temminck et Schlegel) }\end{array}$ & $\begin{array}{l}\text { Miyakoda River, Hamamatsu, Shizuoka } \\
\text { Pref., Japan }\end{array}$ & 1 & LC041207 \\
\hline $\begin{array}{l}\text { P. kamegaii } \\
\text { Iwashita, Hirata et Ogawa, } 2002\end{array}$ & Anguilla japonica & Minato River, Futtsu, Chiba Pref., Japan & 1 & LC041236 \\
\hline P. mundayi sp. $\mathrm{n}$. & A. australis Richardson & Hamamatsu, Shizuoka Pref., Japan* & 2 & LC041234, LC041235 \\
\hline $\begin{array}{l}\text { Pseudodactylogyroides apogonis } \\
\text { (Yamaguti, 1940)** }\end{array}$ & $\begin{array}{l}\text { Apogon semilineatus } \\
\text { (Temminck et Schlegel) }\end{array}$ & Sagami Bay, Misaki, Kanagawa Pref. & 1 & LC041206 \\
\hline
\end{tabular}

No. - no. of specimens; * caught in Tasmania, Australia and sent live to Hamamatsu, Shizuoka Pref., Japan; ** outgroup; ${ }^{1}$ MPM Coll. No. 20990 (Clade A), 20991A-20991F (Clade B).

distance within Pseudodactylogyrus spp. of eels were calculated with the K2 model using MEGA6.

Some differences in ITS2 sequences were found among individuals initially identified as one of the new species (see Table 1). To determine whether these differences corresponded with any differences in morphology, seven additional specimens from the Burnett River were fixed in $100 \%$ ethanol and the body was sectioned into two parts under a stereomicroscope. The anterior part was used for molecular analysis and the posterior (mainly the haptor) was remounted in GAP for examination of haptoral sclerites.

\section{RESULTS}

Family Pseudodactylogyridae Ogawa, 1986

Subfamily Pseudodactylogyrinae Ogawa, 1986

Genus Pseudodactylogyrus Gusev, 1965

Pseudodactylogyrus gusevi sp. n.

Fig. 2

ZooBank number for species:

urn:1sid:zoobank.org:act:50DC807D-4E5E-4717-B3B3-744A699C8A0F

Synonym: Pseudodactylogyrus bini sensu Gusev, 1965 ex Anguilla reinhardtii

Description (based on 9 stained and 19 GAP specimens): Body elongate, slightly tapering at both ends, with widest part at level of testis or post-testicular region, 940-1580 $(1340 ; \mathrm{n}=9)$ long, 220-310 (270; $\mathrm{n}=9)$ wide. Haptor transversely wide, $89-123(106 ; \mathrm{n}=9)$ long, $128-173(150$; $\mathrm{n}=9$ ) wide. Pair of hamuli (anchors), stout and robust, situated medially in haptor. Supplementary piece united with root of internal process of hamulus, folded ventrally or unfolded, its junction thin and flexible. Hamulus with or without supplementary piece $74-84(80 ; \mathrm{n}=17)$ and $67-75(71 ; n=19)$ long, respectively. Supplementary piece curved inward, tapering distally, 21-27 (24; $\mathrm{n}=19)$ long, with small projection near base of outer ridge. Internal process almost straight and square or slightly curved outward from middle, $16-19(17 ; \mathrm{n}=19)$ long, $16-19(17 ; \mathrm{n}=18)$ wide. When supplementary piece unfolded, combined length of supplementary piece and internal process 36-43 $(40 ; \mathrm{n}=17)$ long. External process short, width much narrower than internal process, $8-14(10 ; \mathrm{n}=19)$ long, $8-11$ $(10 ; \mathrm{n}=19)$ wide. Base of hamulus curved inward and slightly tapered, $50-62(57 ; \mathrm{n}=19)$ long, leading to point, 27-32 (29; $\mathrm{n}=19)$. Transverse bar connecting hamuli straight, situated ventrally to hamuli, swollen at both ends, 44-54 (49; $\mathrm{n}=19), 10-17(12 ; \mathrm{n}=19)$ wide. Marginal hooks of larval type, in 7 pairs, $16-19(17 ; n=19)$ long: 6 pairs located along margin of the haptor; 1 pair in centre of haptor, just beside hamuli. Cement gland well developed, $203-306(246 ; n=8)$ long, i.e. $15.5-23.0 \%$ of body length, situated posterior to vitellarium in body proper, opening on ventral surface of haptor.

Anterior end of body somewhat truncated. Three pairs of head organs opening subterminally on both sides of anterior region. Two pairs of eye spots located near anterior end of pharynx. Secretory cells of head organ in 2 pairs, located on each side just posterior to head organ and posterior to pharynx. Mouth opening at same level as eye spots. Pharynx barrel-shaped, 56-81 (68; $\mathrm{n}=9)$ long, 42-74 (57; $\mathrm{n}=9$ ) wide. Oesophagus short. Postpharyngeal gland cells of 2 types, opening to each side of oesophagus, one a mass of small cells closely attached to oesophagus, the other consists of 2 or 3 large, granular cells located outside small cells. Intestine bifurcated, run on both sides of body, uniting in front of cement gland.

Testis ellipsoidal or elongate, medial, 100-245 (190; $\mathrm{n}=9)$ long, $109-144(120 ; \mathrm{n}=9)$ wide. Vas deferens emerging from front edge of testis, looping around sinistral intestinal limb, narrowing in width and ascending in intercaecal area, forming vesicula seminalis before turning backward. Vesicula seminalis directed anteriorly and then posteriorly, sausage-shaped, 35-50 $(41 ; \mathrm{n}=9)$ long in straight line, $8-15(11 ; \mathrm{n}=9)$ wide, leading into base of copulatory tube. Prostatic reservoir spherical, surrounded by thick muscle bundles, $21-37(30 ; n=9)$ in diameter. Prostatic cells distributed around male copulatory complex in intercaecal space. Male copulatory complex consisting 

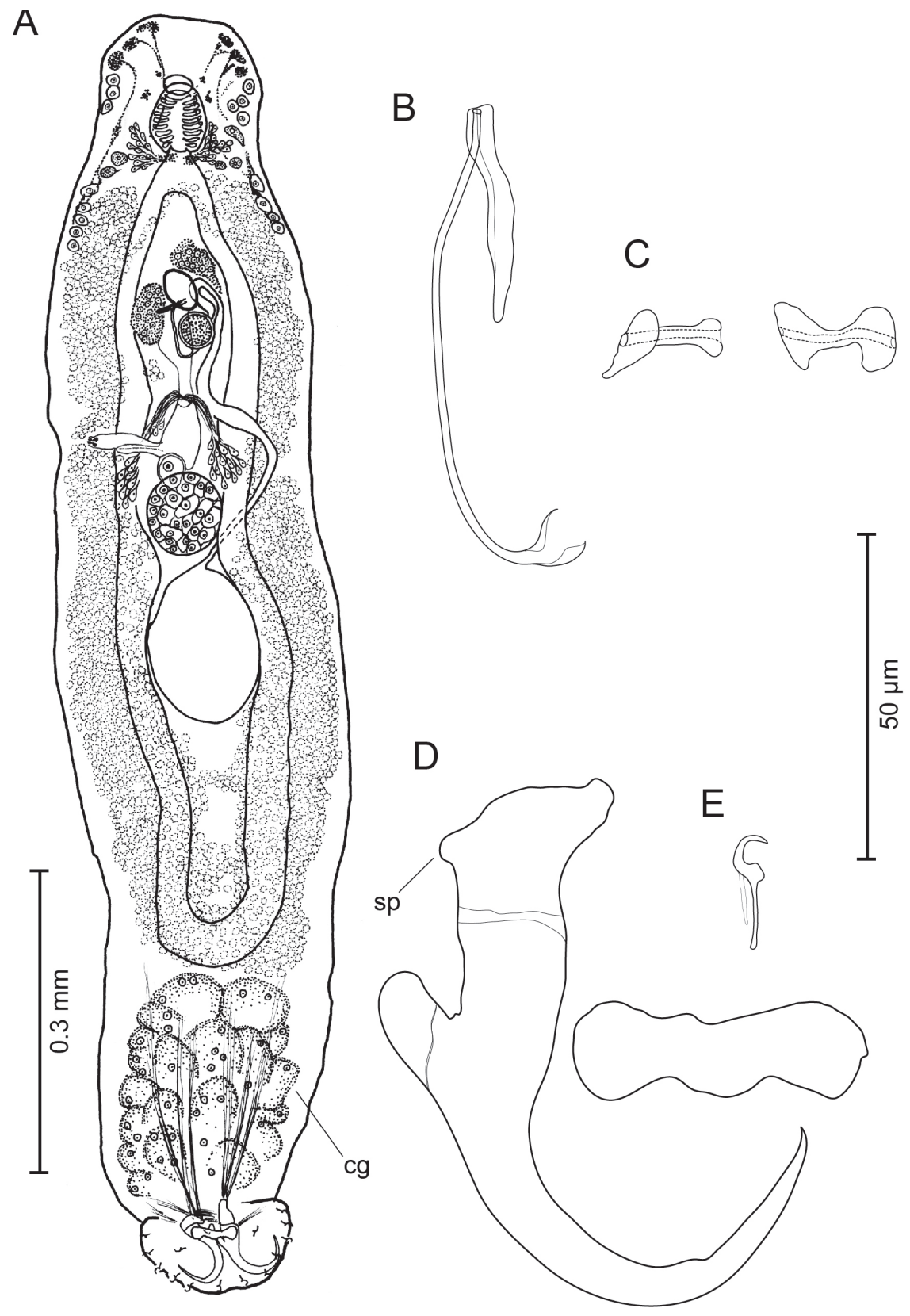

Fig. 2. Pseudodactylogyrus gusevi sp. n. from Anguilla reinhardtii. A - holotype (MPM 20983), ventral view; B-E - sclerotised parts of paratypes; B - male copulatory complex (MPM 20988); C - vagina (left: weakly sclerotised vagina from young adult, right: well sclerotised vagina from fully developed adult) (MPM 20987); D - hamulus and bar (MPM 20988); E - marginal hook (MPM 20988). Abbreviation: $\mathrm{cg}$ - cement gland; sp - small projection.

of arch-form tube and accessory piece. Tube ensheathed by muscles along whole length, curved inward almost at right angle toward its base, rather straight toward its tip, 78-96 $(85 ; \mathrm{n}=19)$ long along its curved line, having constant width, $1-2(2 ; n=19)$ wide, except at funnel-shaped base, $5-8(6 ; \mathrm{n}=19)$ wide. Accessory piece a straight, grooved rod, 34-41 (38; $n=19)$ long, $2-5(3 ; n=19)$ wide. Tube reaching genital pore, located anterior to prostatic reservoir.

Ovary spherical, situated immediately anterior to testis and smaller than testis, sometimes overlapping with anterior part of testis, 46-87 $(75 ; \mathrm{n}=9)$ long, 56-84 (71; $\mathrm{n}=9$ ) wide. Oviduct starting from anterior edge of ovary to form fertilisation chamber, having small outgrowth on right side. Vagina almost straight, opening 17-37 (26; $\mathrm{n}=8$ ) from dextral lateral margin. Distal end a sclerotised, dumbbell-shaped tube, with both ends thickened, 15-21 $(17 ; \mathrm{n}=18)$ in a straight line, $16-22(19 ; \mathrm{n}=18)$ long along its curve, $2(\mathrm{n}=17)$ wide. Fertilisation chamber leading to ootype. Mehlis' glands opening at posterior end of ootype, with gland cells on both sides of ovary. Uterus leads to genital pore together with male copulatory complex. No egg observed in uterus. Vitellarium coexistent with intestine.

Ty pe host: Anguilla reinhardtii Steindachner (Anguillidae). Other host: Anguilla australis Richardson (Anguillidae).

Type locality: Burnett River at Bundaberg, Queensland, Australia $\left(24^{\circ} 52^{\prime} \mathrm{S} ; 152^{\circ} 21^{\prime} \mathrm{E}\right), 9$ and 10 January 1998. 


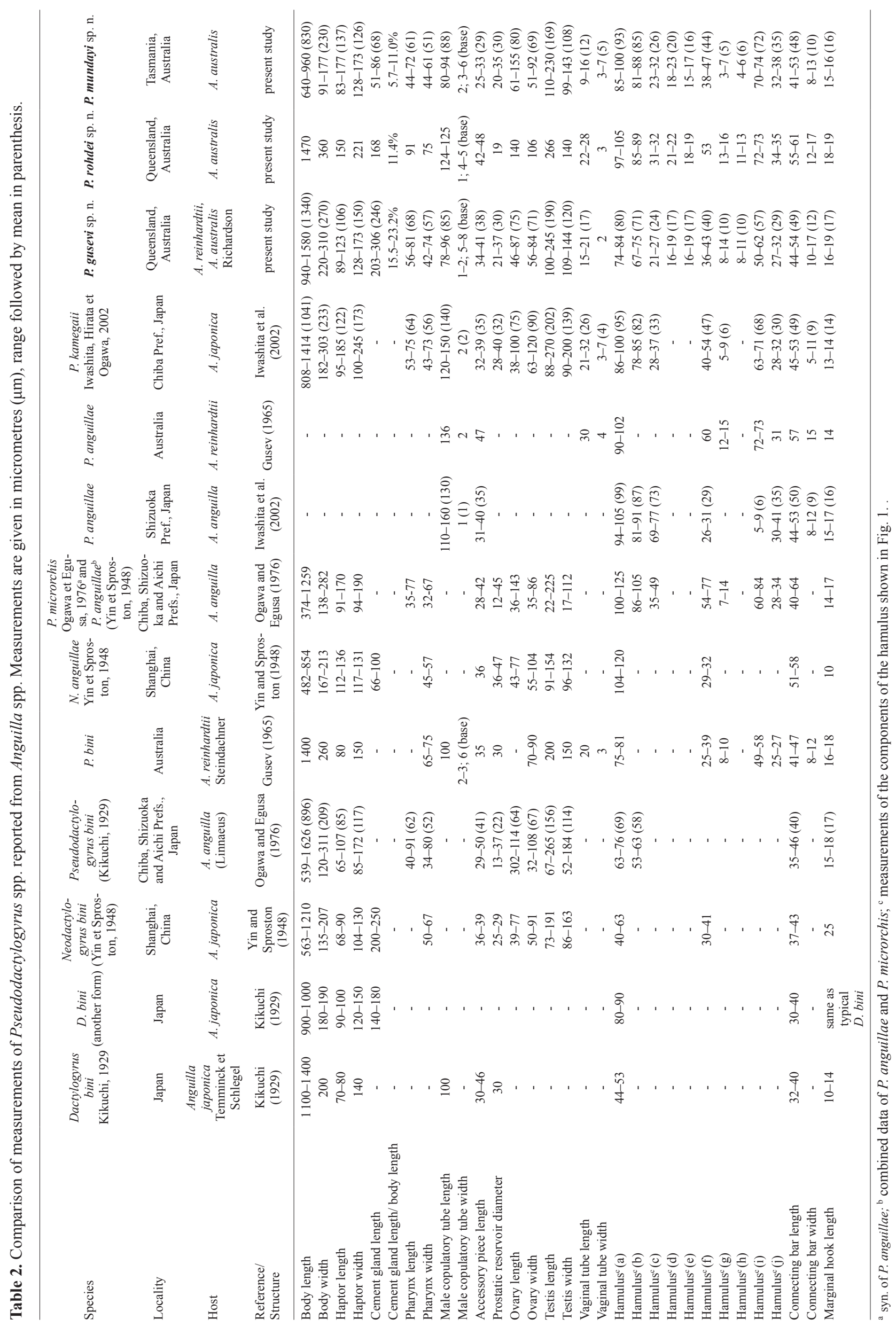


Other localities : Noosa, Queensland, Australia $\left(26^{\circ} 29^{\prime} \mathrm{S}\right.$; $\left.153^{\circ} 01^{\prime} \mathrm{E}\right), 8$ and 9 January 1999; South Brisbane, Queensland, Australia $\left(27^{\circ} 28^{\prime} \mathrm{S} ; 153^{\circ} 02^{\prime} \mathrm{E}\right), 6$ February 1998; Redland Bay,

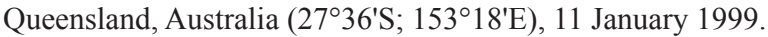

Site: Gills.

Type materia 1: Holotype: Meguro Parasitological Museum, Tokyo (MPM 20983) and 27 paratypes (MPM 20984-20989), Queensland Museum, Brisbane (QM G234715, G234716) and the Institute of Parasitology, Academy of Sciences of the Czech Republic, České Budějovice (IPCAS M-584).

Etymology: The species is named after the late Alexander V. Gusev, who erected the genus Pseudodactylogyrus in 1965, based on specimens collected from Anguilla reinhardtii by the late John C. Pearson.

Remarks. Gusev (1965) identified specimens from $\mathrm{An}$ guilla reinhardtii as $P$. bini, but they differed from those of $P$. bini as originally described by Kikuchi (1929) in the shape of the male copulatory tube: arch-form in Gusev (1965) vs curved in a circle in Kikuchi (1929). P. bini sensu Gusev, 1965 were very similar to $P$. gusevi sp. n., but unfortunately, his specimens were lost (P.I. Gerasev, Zool. Inst., St. Petersburg, Russia - pers. comm.) and thus could not be compared with the present specimens (see Table 2). The general structure and measurements of his $P$. bini are almost completely identical with the present measurements, except for some parts of the female reproductive organs and the hamuli. The vaginal tube is heavily sclerotised at both ends in $P$. gusevi, whereas it was described as sclerotised at only one end in Gusev's P. bini. There is a small outgrowth on the right side of the fertilisation chamber and a small projection on the outer side of the supplementary piece of hamulus in $P$. gusevi, while neither of such structures was described in Gusev (1965). Gusev's description was based on specimens collected by J.C. Pearson. No mention was made on how the specimens were fixed, but most probably they were stained specimens, in which some minute structures like the sclerotised part of the vagina and the supplementary piece of the hamulus are often difficult to observe. The present description of such sclerotised parts were based on specimens fixed in GAP and the small outgrowth of the fertilisation chamber was observed only in specimens fixed in AFA and stained with Heidenhain's iron hematoxylin. Thus, it is thought that the observed morphological differences between our specimens and those of Gusev (1965) are insufficient to consider them as two separate species. We thus conclude that P. bini sensu Gusev, 1965 is identical with P. gusevi sp. n.

Pseudodactylogyrus gusevi can be differentiated from congeners by the morphological characters of the sclerotised parts such as hamuli, male copulatory complex and vagina, and from the most similar species, $P$. bini, by the combination of the following morphological characters: considerably shorter male copulatory tube (78-96 $\mu \mathrm{m}$ in P. gusevi vs 167-212 $\mu \mathrm{m}$ in $P$. bini; $\mathrm{n}=8$; vaginal tube short $(16-22 \mu \mathrm{m})$ with heavily sclerotised ends in $P$. gusevi, compared with a simple, longer $(25-32 \mu \mathrm{m} ; \mathrm{n}=8)$ and lightly sclerotised tube in P. bini; and the presence of a small projection on the supplementary piece of the hamulus in P. gusevi vs the absence of such structure in P. bini.

\section{Pseudodactylogyrus rohdei sp. n.}

Fig. 3

ZooBank number for species:

urn:1sid:zoobank.org:act:AA2CEF0B-58EB-4F78-8179E8F48C11DB5E

Synonym: Pseudodactylogyrus anguillae sensu Gusev, 1965 ex Anguilla reinhardtii.

Description (based on 1 stained and 2 GAP specimens): Body elongate, slightly tapering at both ends, widest part at level of post-testicular region, $1470(n=1)$ long, 360 $(\mathrm{n}=1)$ wide. Haptor transversely wide, $150(\mathrm{n}=1)$ long, $221(\mathrm{n}=1)$ wide. Pair of hamuli large and slender. Hamulus with or without supplementary piece 97-105 $(\mathrm{n}=2)$ and $85-89(n=2)$ long, respectively. Supplementary piece curved inward, tapering distally, 31-32 (n = 2) long, with small projection near base of outer ridge as in $P$. gusevi. Internal process almost straight, slightly wider distally, 21-22 $(\mathrm{n}=2)$ long, 18-19 $(\mathrm{n}=2)$ wide. When supplementary piece unfolded, combined length of supplementary piece and internal process $53(\mathrm{n}=2)$ long. External process short, straight or slightly curved inward, width about half that of internal process, $13-16(n=2)$ long, $11-13(n=2)$ wide. Base of hamulus curved inward and tapered, 72-73 (n=2) long. Point 34-35 $(n=2)$ long. Transverse bar straight, swollen at both ends, 55-61 $(n=2)$ long, $12-17(n=2)$ wide. Marginal hooks $18-19(\mathrm{n}=2)$ long. Cement gland well developed, $168(\mathrm{n}=1)$ long or $11.4 \%$ of body length.

Head organs not clearly observed. Two pairs of eye spots located near anterior end of pharynx. Secretory cells of head organ in 2 pairs, as in P. gusevi. Mouth opens at same level as eye spots. Pharynx barrel-shaped, $91(\mathrm{n}=1)$ long, $75(\mathrm{n}=1)$ wide. Oesophagus short. Postpharyngeal gland cells of 2 types, opening to each side of oesophagus. Intestine bifurcated and running on both sides of body, uniting in front of cement gland.

Testis elongate, medial, $266(n=1)$ long, $140(n=1)$ wide. Vas deferens looping around sinistral intestinal limb, narrowing in width and ascending in intercaecal area, turning backward, leading into base of copulatory tube. Vesicula seminalis not clearly formed. Prostatic reservoir 19 $(n=1)$ in diameter. Prostatic cells distributed around prostatic reservoir in space between intestinal limbs. Male copulatory complex a sclerotised tube, $124-125(\mathrm{n}=2)$ long along its curved line, $1(\mathrm{n}=2)$ wide with funnel-shaped base $4-5(n=2)$ wide, accompanied by accessory piece, straight and grooved, 42-48 ( $\mathrm{n}=2)$ long, 4-5 ( $\mathrm{n}=2)$ wide.

Ovary spherical, overlapping with anterior part of testis, $140(\mathrm{n}=1)$ long, $106(\mathrm{n}=1)$ wide. Oviduct forming fertilisation chamber anterior to ovary. No outgrowth of fertilisation chamber observed. Vagina dextral, $47(n=1)$ from lateral margin. Distal end of vagina a sclerotised tube, straight or bent medially, 22-28 $(\mathrm{n}=2)$ long, $3(\mathrm{n}=2)$ wide. No egg observed in uterus. Vitellarium co-existent with intestine.

Type host: Anguilla australis Richardson (Anguillidae).

Type locality: Noosa, Queensland, Australia $\left(26^{\circ} 29^{\prime} \mathrm{S}\right.$; $\left.153^{\circ} 01^{\prime} \mathrm{E}\right), 9$ January 1999. 

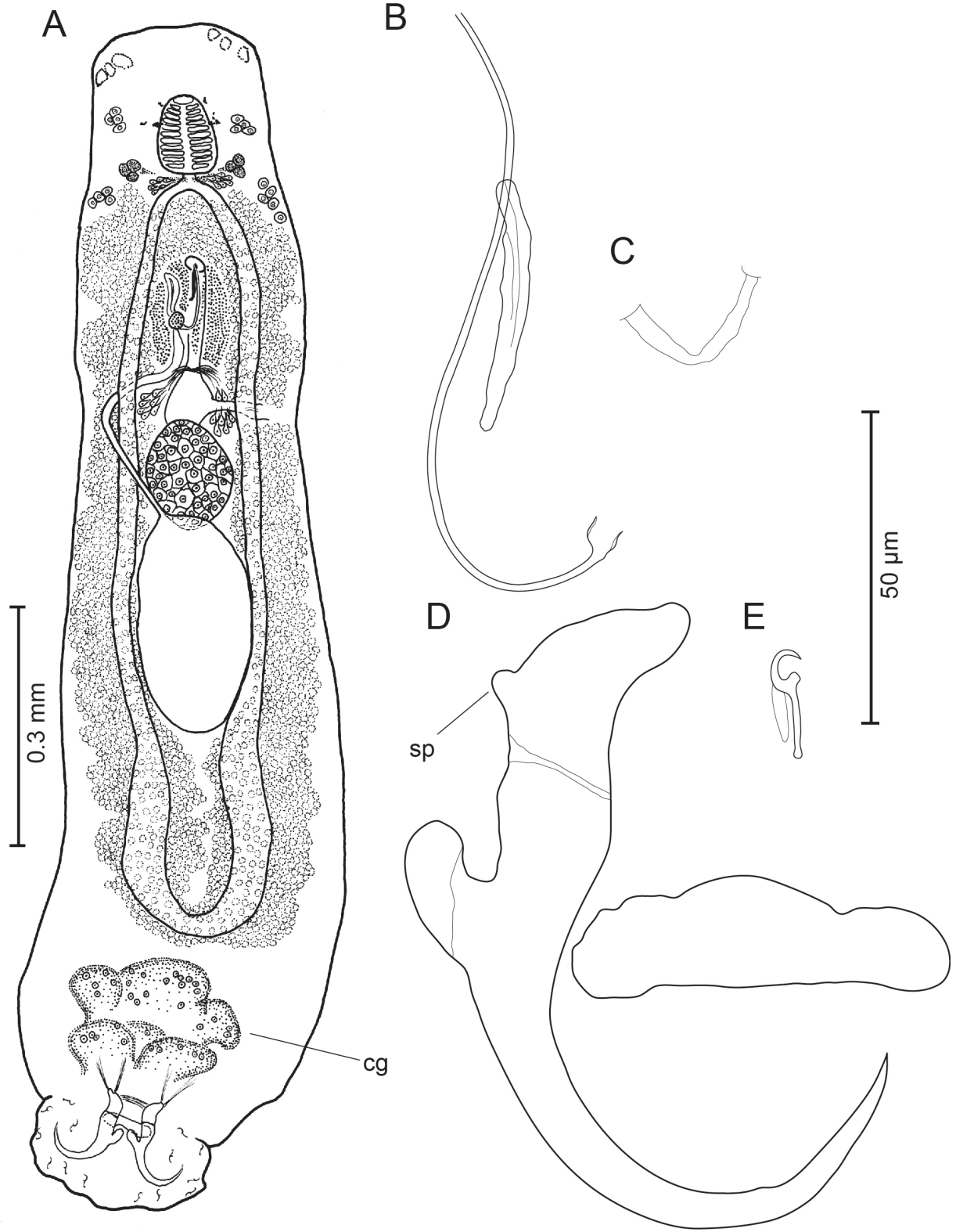

Fig. 3. Pseudodactylogyrus rohdei sp. n. from Anguilla australis Richardson. A - holotype (MPM 20992), dorsal view; B-E - sclerotised parts of paratypes; B - male copulatory complex (QM G234717); C - vagina (QM G234717); D - hamulus and bar (MPM 20993); E - marginal hook (MPM 20993). Abbreviation: cg - cement gland; sp - small projection.

Site: Gills.

Type material: Holotype (MPM 20992) and 2 paratypes (MPM 20993 and QM G234717).

E ty mology: The species is named after Klaus Rohde, a distinguished fish parasitologist, Emeritus Professor of the University of New England, Australia.

Remarks. We compare $P$. rohdei sp. n. with specimens from $A$. reinhardtii described as $P$. anguillae by Gusev (1965). His description was simple and no measurements were given of the body, haptor, pharynx, prostatic reservoir, testis or ovary. His measurements of the sclerotised parts correspond very well with ours, except for the length of marginal hooks: 14 according to Gusev, compared with 18-19 in GAP specimens of the present study. A small projection on the outer side of the supplementary piece of the hamulus was also not described in Gusev (1965). However, considering that these differences are small, we concluded that $P$. anguillae sensu Gusev, 1965 collected from $A$. reinhardtii is conspecific with $P$. rohdei sp. n. described in this paper. His specimens were collected from $A$. reinhardtii, whereas ours were collected from $A$. australis.

$P$. rohdei sp. n. is most similar to $P$. anguillae, but can be easily discriminated by the length of the cement gland (much shorter in P. anguillae) and the shape and size of the hamulus (small projection of the supplementary piece absent in $P$. anguillae; external process shorter in $P$. anguillae) (Yin and Sproston 1948, Ogawa and Egusa 1976). $P$. rohdei sp. n. is also similar to $P$. gusevi, but can be distinguished by the size of the male copulatory tube (124-125 $\mu \mathrm{m}$ in $P$. rohdei vs 78-96 $\mu \mathrm{m}$ in $P$. gusevi) and the size of hamuli (without the supplementary piece) (85-89 $\mu \mathrm{m}$ vs 67-75 $\mu \mathrm{m})$. 


\section{Pseudodactylogyrus mundayi sp. n.}

ZooBank number for species:

urn:1sid:zoobank.org:act:C73E73FD-F48F-4268-B88E-5FEE1C17D176

Description (based on 8 stained and 16 GAP specimens): Body elongate, slightly tapering at both ends, widest part at level of testis or post-testicular region, 640-960 (830; $\mathrm{n}=8)$ long, 91-177 (230; $\mathrm{n}=8)$ wide. Haptor transversely wide, 83-177 (137; n=6) long, 128-173 (126; $\mathrm{n}=8)$ wide. Pair of hamuli slender. Hamulus with and without supplementary piece $85-100(93 ; \mathrm{n}=12)$ and $81-88(85$; $\mathrm{n}=16$ ) long, respectively. Supplementary piece curved inward and tapering distally, 23-32 (26; $\mathrm{n}=14)$ long. No small projection formed along outer ridge of supplementary piece. Internal process almost square and slightly curved outward, 18-23 (20; $\mathrm{n}=16)$ long, 15-17 (16; $\mathrm{n}=16)$ wide. When supplementary piece unfolded, combined length of supplementary piece and internal process being 38-47 (44; $\mathrm{n}=13$ ) long. External process short, width being much narrower than that of internal process, $3-7(5 ; \mathrm{n}=16)$ long, 4-6 (6; $\mathrm{n}=16)$ wide. Base of hamulus curved inward, slightly tapered, $70-74(72 ; \mathrm{n}=16)$ long, leading to point, $32-38(35 ; \mathrm{n}=16)$. Transverse bar straight, swollen at both ends, $41-53(48 ; \mathrm{n}=16)$ long, $8-13(10 ; \mathrm{n}=16)$ wide. Marginal hooks of larval type, in 7 pairs, 15-16 (16; $\mathrm{n}=14$ ) long: 6 pairs located along margin of haptor; 1 pair in centre of haptor, just beside hamuli. Cement gland short, $51-86(68 ; n=7)$ long or $5.7-11.0 \%$ of body length.

Three pairs of head organs opening subterminally on both sides of anterior region. Two pairs of eye spots located near anterior end of pharynx. Secretory cells of head organ in 2 pairs, located on each side just posterior to head organ and pharynx. Mouth opening at same level as eye spots. Pharynx barrel-shaped, 44-72 (61; $\mathrm{n}=8)$ long, 44-61 (51; $\mathrm{n}=8$ ) wide. Oesophagus short. Postpharyngeal gland cells of 2 types open on each side of oesophagus. Intestine bifurcated and running on both sides of body, uniting in front of cement gland.

Testis ellipsoidal or elongate, situated in middle of body, 110-230 (169; $\mathrm{n}=8)$ long, 99-143 (108; $\mathrm{n}=8)$ wide. Vas deferens looping around left intestinal limb, narrowing in width and ascending in intercaecal area, forming vesicula seminalis before turning backward. Vesicula seminalis directed anteriorly and then posteriorly, sausage-shaped, 29-38 $(33 ; \mathrm{n}=7)$ long in straight line, 56-70 $(62 ; \mathrm{n}=7)$ long along a curved line, $8-17(14 ; \mathrm{n}=8)$ wide, leading into base of copulatory tube. Prostatic reservoir spherical, surrounded by thick muscle bundles, 20-35 $(30 ; n=8)$ in diameter. Prostatic cells distributed around male copulatory organ in intercaecal space. Male copulatory tube short, 80-94 (88; $\mathrm{n}=16)$ long along its curved line, of constant width, $2(\mathrm{n}=16)$ wide and its base, funnel-shaped, 3-6 $(4 ; n=16)$ wide. Accessory piece a straight, grooved rod, 25-33 (29; $\mathrm{n}=16)$ long, $3-5(4 ; \mathrm{n}=16)$ wide. Genital pore located anterior to prostatic reservoir.

Ovary spherical, situated just in front of testis, smaller than testis, sometimes overlapping with anterior of testis, 61-155 (80; $\mathrm{n}=8)$ long, 51-92 (69; $\mathrm{n}=8)$ wide. Oviduct with small outgrowth on right side in front of ovary, leads to ootype and uterus. Vagina opening dextrally, 6-29 (17; $\mathrm{n}=8$ ) from right lateral margin, almost straight tube. Distal end of vagina a poorly sclerotised tube, sometimes unrecognisable, 9-16 $(12 ; \mathrm{n}=11)$ long in a straight line, 9-17 $(13 ; n=9)$ long along its curve, $3-7(5 ; n=13)$ wide. Genital pore opening at level of vesicula seminalis. Vitellarium co-existent with intestine.

Type host: Anguilla australis Richardson (Anguillidae).

Type locality: Tasmania, Australia (precise locality not specified). The host eels were transferred alive to Shizuoka Prefecture, Japan $\left(34^{\circ} 42^{\prime} \mathrm{N} ; 137^{\circ} 38^{\prime} \mathrm{E}\right)$ and sampled on 23 March 2010 for parasitological examination.

Site: Gills.

Type material: Holotype: (MPM 20994) and 23 paratypes (MPM 20994-20996; QM G234718, G234719; IPCAS M-585).

Etymology: The species is named after the late Barry L. Munday, an outstanding Tasmanian authority in fish pathology and parasitology.

Remarks. P. mundayi sp. n. is most similar to P. kamegaii in general morphology, but can be discriminated from the latter in that the male copulatory tube (80-94 $\mu \mathrm{m}$ long) is considerably shorter than that of $P$. kamegaii (120-150 $\mu \mathrm{m}$ long), and the vaginal tube (9-16 $\mu \mathrm{m}$ long) is shorter than that of P. kamegaii (21-32 $\mu \mathrm{m}$ long) (Iwashita et al. 2002). Pseudodactylogyrus mundayi differs from $P$. kamegaii not only in morphology, but also in host species (A. australis compared with $A$. japonica) and habitat (fresh water vs sea water) (Iwashita et al. 2002, Katahira et al. 2012).

\section{Molecular analysis}

The phylogenetic tree of six Pseudodactylogyrus spp. including two of the three newly described species (P. gusevi and P. mundayi) is shown in Fig. 5. All Pseudodactylogyrus spp. analysed in this study formed a monophyletic group. Among them, P. haze is located in the most basal position. Its ITS2 sequence is very different from that of the other species; the evolutionary distance between $P$. haze and Pseudodactylogyrus spp. of eels is 0.5447 , whereas mean distance among Pseudodactylogyrus spp. of eels is 0.0370. In contrast, Pseudodactylogyrus spp. from Australian and Japanese eels are closely related. They are divided into three lineages by their distribution, i.e. from Japanese waters ( $P$. anguillae, $P$. bini and P. kamegaii), Australian mainland waters (P. gusevi sp. n.) and Tasmanian waters (P. mundayi sp. n.). Specimens of $P$. gusevi are divided into two groups (Clade A and B). Clade A consists of specimens collected only from the Burnett River $(n=6)$, whereas clade B consists of specimens collected from all localities, namely Burnett River $(n=7)$, Noosa $(n=8)$, Redland Bay $(n=4)$ and South Brisbane $(n=1)$. Among the seven additional specimens of $P$. gusevi from the Burnett River examined for both morphology (haptoral sclerites) and the ITS2 sequence, one (MPM 20990) belonged to Clade A, whereas the remaining six (MPM 20991A-20991F) belonged to Clade B. No morphological differences were de- 


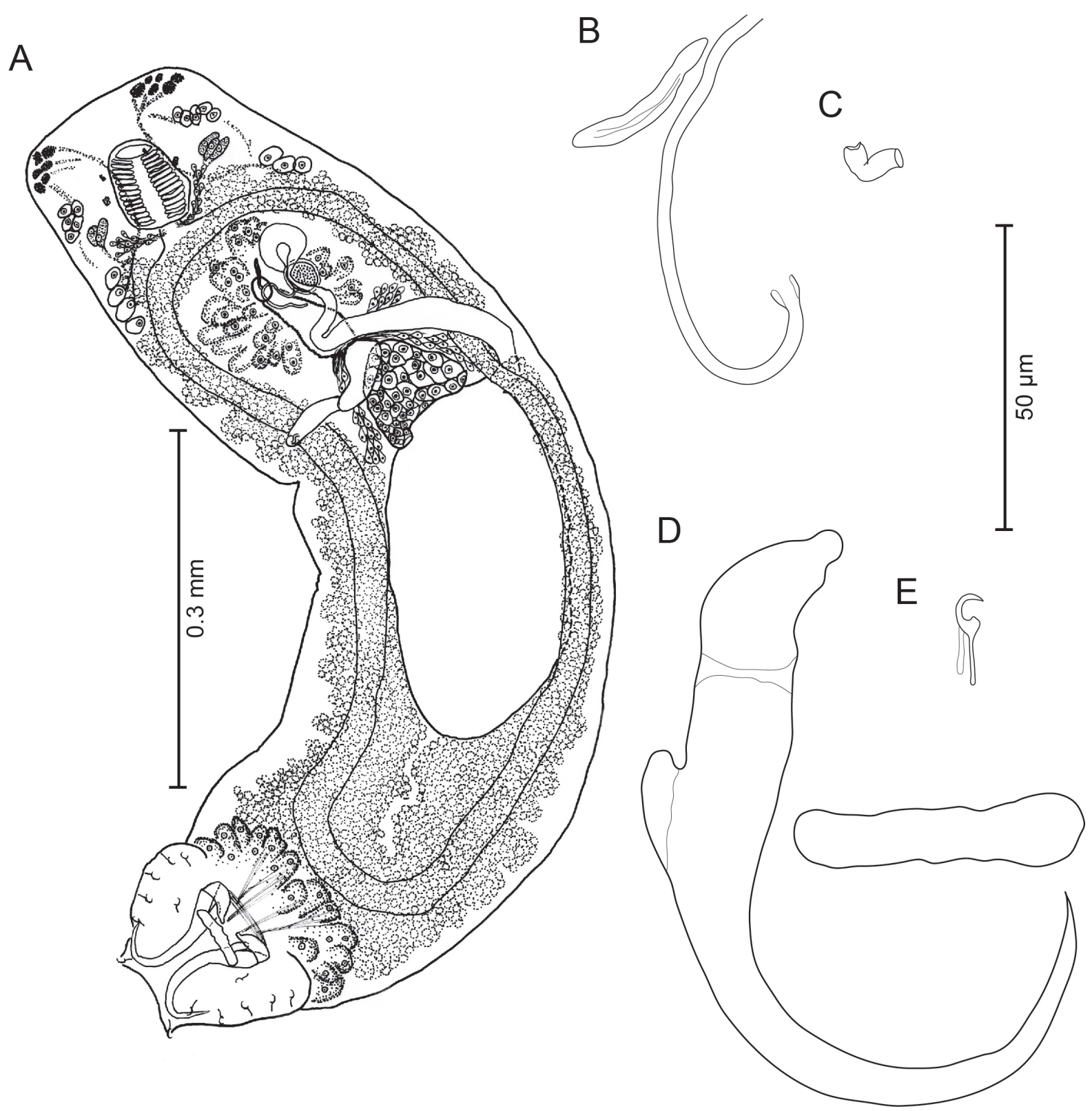

Fig. 4. Pseudodactylogyrus mundayi sp. n. from Anguilla australis Richardson. A - holotype (MPM 20994), ventral view; B-E - sclerotised parts of paratypes; B - male copulatory complex (MPM 20996); C - vagina (MPM 20996); D - hamulus and bar (MPM 20996); E - marginal hook (MPM 20996).

tected in the hamulus and transverse bar among the seven specimens.

\section{DISCUSSION}

Pseudodactylogyrus bini and P. anguillae were originally described from the gills of Japanese eel, Anguilla japonica in Japan and in China, respectively (Kikuchi 1929, Yin and Sproston 1948). Since then, these monogeneans have been reported from different species of ells (Anguilla spp.) in different geographical regions. There is evidence that infection of Anguilla spp., other than the type host $A$. japonica, are results of human activities, by which infected A. japonica was introduced to localities outside of its natural distribution, or other Anguilla spp. were introduced to localities where A. japonica was naturally distributed. Once the Pseudodactylogyrus infection became estab- lished in some parts of Europe, commercial movements of infected A. anguilla became another source of parasite invasion within other parts of Europe and elsewhere. There are also some unconfirmed sources of origin like $P$. anguillae infection of $A$. mossambica in South Africa (Christison and Baker 2007), P. bini and P. anguillae infection of A. mossambica and A. marmorata in the Island of Reunion (Sasal et al. 2008), and $P$. anguillae infection of $A$. bicolor McClelland in Indonesia (K. Buchmann, Univ. of Copenhagen, Frederiksberg $\mathrm{C}$, Denmark - pers. comm.).

Live A. australis is imported to Japan from Australia and kept in fresh water at an eel dealer's facilities until consumed for food. Pseudodactylogyrus mundayi was collected from such eels purchased from the dealer. Anguilla japonica and A. marmorata are eel species native to Japan, from which three species of Pseudodactylogyrus, i.e. 


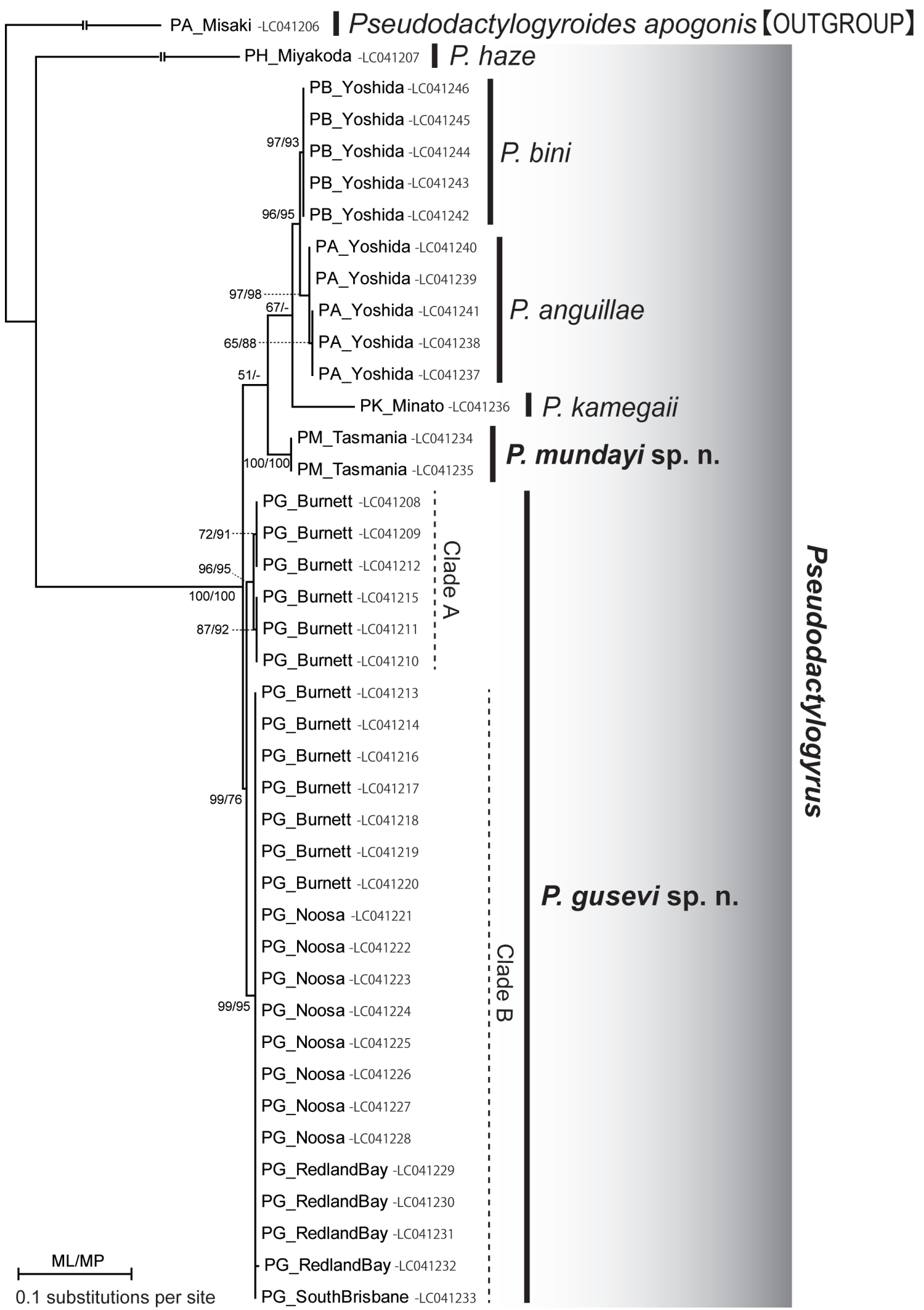

Fig. 5. Phylogenetic tree of species of Pseudodactylogyrus Gusev, 1965 constructed based on ITS2 sequences.

P. bini, P. anguillae and P. kamegaii from the former species of eel [note: $P$. anguillae was first reported in Japan by Kikuchi (1929) as another form of Dactylogyrus bini; Table 2] and P. bini and P. anguillae from the latter have been recorded (Kikuchi 1929, Iwashita et al. 2002; Kata- hira and Nagasawa 2014). No infection of P. mundayi has been detected in eels in Japan so far, but there is a risk of introduction of this new species infecting native eels in Japan. Japanese eel, A. japonica, is a highly valuable fish species and extensively cultured in Japan. This eel species 
has been included in the red list of endangered species by the International Union for Conservation of Nature and Natural Resources after a long history of overfishing of young elvers used for aquaculture (Tatsukawa 2003). Preventive measures should urgently be taken against possible infection of Japanese eelswith P. mundayi.

Kennedy (1998) reported $P$. bini and $P$. anguillae infection of Anguilla reinhardtii in several localities of Queensland, Australia. It is possible that his Pseudodactylogyrus spp. correspond to the present Pseudodactylogyrus, especially $P$. gusevi and $P$. rohdei. As three new species are proposed in this paper and Kennedy (1998) did not describe morphological characteristics of the two species he collected, confirmation of the identification of his specimens is required. His specimens had been deposited at International Institute of Parasitology, UK, but they have been lost after the closure of the institute in 1998 (D.I. Gibson, Nat. Hist. Mus., London, UK - pers. comm.). This made it impossible to compare his specimens with the present ones.

Wu et al. (1988) proposed a new species Dactylogyrus bialatus Wu, Wang et Jian, 1988 from the gills of Synechogobius ommaturus (Richardson) (Gobiidae) in Zhejian Province, China. They described the sclerotised parts only, but this species apparently belongs to the genus Pseudodactylogyrus, as it has the characteristic supplementary piece at the root of the hamulus and seven pairs of marginal hooks are of larval type. Thus a new combination, Pseudodactylogyrus bialatus (Wu, Wang et Jian, 1988) comb. n. ZooBank number for species: urn:lsid:zoobank.org:act:36152620-64DB4A1D-B59D-DE76CD94BB8F, is proposed here, which can be discriminated from the most similar $P$. haze by having a larger hamulus (78-89 $\mu \mathrm{m}$ long $v s$ 60-71 $\mu \mathrm{m}$ long) and a larger accessory piece of the male copulatory complex (45-48 $\mu \mathrm{m}$ long $v s$ 25-32 $\mu \mathrm{m}$ long). With the three new species and one new combination proposed in this paper, the genus Pseudodactylogyrus is emended and is now comprised of eight species. A key to species of Pseudodactylogyrus is given below.

\section{Amended diagnosis of Pseudodactylogyrus}

Pseudodactylogyridae. Body elongated with three pairs of head organs. Head truncated. Haptor with one pair of hamuli, one connecting bar and 14 marginal hooks. One pair of hamuli directing ventrally, with connecting bar and supplementary pieces, which are separated from or united with roots of hamuli. Marginal hooks of larval type, one pair central and six pairs peripheral. Cement gland well developed. Two pairs of eye spots present. Pharynx well developed. Postpharyngeal gland present. Intestinal limbs without diverticula, united posteriorly. Testis rounded or elongated, median, equatorial. Vas deferens looping around left intestinal limb. Vesicula seminalis formed by dilatation of vas deferens. Male copulatory complex consisting of a simple tube and accessory piece. Prostatic reservoir single, directly attached to copulatory tube. Genital pore postbifurcal. Ovary rounded or elongated, median, immediately pretesticular. Vagina opening dextrally, armed or unarmed. Receptaculum seminis present. Vitellarium co- existent with intestine. Parasites of freshwater and marine teleosts.

Tyре species: Pseudodactylogyrus bini (Kikuchi, 1929).

\section{Key to species of Pseudodactylogyrus Gusev, 1965}

1 Accessory piece of male copulatory complex rod-shaped, much shorter than copulatory tube 2

- Accessory piece of male copulatory complex hookshaped terminally, almost same length as copulatory tube 6

2 Copulatory tube longer than $100 \mu \mathrm{m} ; 2 \mu \mathrm{m}$ wide ......... ........... P. kamegaii Iwashita, Hirata et Ogawa, 2002

- Copulatory tube longer than $100 \mu \mathrm{m} ; 1 \mu \mathrm{m}$ wide ...... 3

- Copulatory tube shorter than $100 \mu \mathrm{m}$........................ 5

3 Supplementary piece of hamulus with small projection near base of outer ridge ................... P. rohdei sp. n.

- Supplementary piece of hamulus without such projection ................................................. 4

4 Hamulus stout, less than $80 \mu \mathrm{m}$ long including supplementary piece ..................... P. bini (Kikuchi, 1929)

- Hamulus slender, nearly $100 \mu \mathrm{m}$ or longer including supplementary piece

P. anguillae (Yin et Sproston, 1948)

5 Vagina poorly sclerotised, curved ..... P. mundayi sp. n.

- Vagina well sclerotised, thickened on both ends, almost straight P. gusevi sp. n.

6 Accessory piece of male copulatory complex longer than $60 \mu \mathrm{m}$; transverse bar longer than $60 \mu \mathrm{m}$ P. bialatus comb. $\mathrm{n}$.

- Accessory piece of male copulatory complex shorter than $50 \mu \mathrm{m}$; transverse bar shorter than $50 \mu \mathrm{m}$ P. haze Ogawa, 1984

Ling (1973) described Pseudodactylogyrus pseudobagrus from the gills of Pseudobagrus fulvidraco (= Tachysurus fulvidraco) in China. The parasite was characterised by a pair of hamuli, a pair of identical, long connecting bars, seven pairs of marginal hooks of larval type, the male copulatory complex consisting of a simple tube and an accessory piece with a succate base and bifurcate tip. This species is different from the members of Pseudodactylogyrus in the presence of two connecting bars and absence of a supplementary piece of the hamulus. Ling (1973) may have had no knowledge of Pseudodactylogyrus. His genus was later transferred to Sinidactylogyrus by Zhang (1981), but the systematic position of $S$. pseudobagrus (Ling, 1973 ) is not clear.

In the present phylogenetic tree, $P$. gusevi collected from $A$. reinhardtii in the Burnett River was divided into two groups (Clades A and B). Specimens collected from the other localities, namely Noosa, South Brisbane and Redland Bay, all belonged to Clade B. Although no morphological differences were observed among $P$. gusevi 
specimens from the Burnett River, a possibility remains that $P$. gusevi is comprised of two cryptic species.

Morphologically, P. gusevi is most similar to P. bini, while molecularly, $P$. gusevi and $P$. bini were located in a distant position among Pseudodactylogyrus spp. of eels. The apparent morphological similarity between $P$. gusevi and $P$. bini is probably a result of convergence. Among the three new species of Pseudodactylogyrus, P. gusevi and $P$. rohdei are closely related morphologically; both have very similar anatomy (testis, ovary, cement gland, etc.), male copulatory complex and hamulus, which has a small projection on the outer ridge of its supplementary piece. This indicates that the two monogeneans may have evolved from a common ancestral species. When the present data and those of Gusev (1965) are combined, both A. reinhardtii and $A$. australis are hosts of $P$. rohdei in the Australian mainland. Phylogenetic analysis of the host eels indicates that $A$. reinhardtii, together with $A$. japonica, belongs to the Indo-Pacific group, whereas $A$. australis belongs to the Oceanian group (Minegishi et al. 2005). Although the geographical distribution of the two Australian eels overlaps, they are rather distant from each other phylogenetically. It is possible that $P$. rohdei has evolved either on the Indo-Pacific or on the Oceanian group host in the Australian mainland and later expanded its host range to the other group host.

The present phylogenetic tree suggests that among the eel pseudodactylogyrids, $P$. gusevi diverged first, followed by $P$. mundayi, which forms a sister clade with the three Pseudodactylogyrus spp. of A. japonica, although we could not obtain high statistical supports. The latter species of Pseudodactylogyrus may have evolved into three independent species as ancestral $A$. japonica dispersed to the North Pacific region. Similarly, $P$. mundayi and $P$. gusevi may have evolved as ancestral $A$. australis and $A$. reinhardtii dispersed to the Oceanic region, respectively.

The natural host of $P$. bini and P. anguillae is A. japoni$c a$ and records of these pseudodactylogyrids from other Anguilla spp. like $A$. anguilla and $A$. rostrata were the results of international translocations of $A$. japonica to areas outside its natural distribution area. In contrast, the record of $P$. bini and $P$. anguillae from wild $A$. marmorata in Japan (Katahira and Nagasawa 2014) shows the two pseudodactylogyrids have two natural hosts, $A$. japonica and A. marmorata. Similarly, $A$. reinhardtii and $A$. australis are considered as natural hosts of $P$. rohdei. Whether or not $P$. mundayi infects $A$. reinhardtii in Tasmania remains to be clarified.

Members of Pseudodactylogyrus comprise those infecting anguillid eels and gobiid fishes. The present molecular data indicate that Pseudodactylogyrus spp. infecting Anguilla spp. (P. bini, P. anguillae, P. kamegaii, P. gusevi and $P$. mundayi) are monophyletic, suggesting their speciation occurred parallel to the host speciation. It is probable that a similar process of speciation has occurred in $P$. haze and P. bilalatus comb. n. on the gobiid hosts.

Species of Pseudodactylogyroides Ogawa, 1986 retain one pair of vestigial dorsal hamuli, implying that they are an ancestral group of the members of Pseudodacylogyrus - see
Ogawa (1986). Pseudodactylogyroides spp. have been recorded on fishes of the families Apogonidae, Gobiidae and Eleotridae (the latter two belonging to the suborder Gobioidei) (Ogawa 1986, Lim 1995, Li 2004). It is hypothesised that ancestral species of Pseudodactylogyrus were parasites of unspecified marine fishes including gobioids and apogonids, and that they switched hosts to ancestral anguillids to have evolved to the present eel pseudodactylogyrids.

Three hypotheses can be proposed about the origin of the present Pseudodactylogyrus of eels. A host switch might have occurred twice independently: one among ancestral eels of the Oceanic group including A. australis, and the other among the Indo-Pacific group including $A$. japoni$c a$ and $A$. reinhardtii (first hypothesis). Alternatively, the present species originated from a host switch that occurred before the separation of the Atlantic group (A. anguilla and $A$. rostrata) and Oceanic group from the Indo-Pacific group (second hypothesis), or from a host switch within the Indo-Pacific group after their separation from those of the Atlantic and Oceanic group (third hypothesis) (see Minegishi et al. 2005, Aoyama 2009 for information regarding separation of the anguillid groups).

There has been no record of natural Pseudodactylogyrus infections among the Atlantic group, except for infections caused by anthropogenic activities. Besides, Hine (1978) did not find even a single pseudodactylogyrid from 459 New Zealand longfin eel, Anguilla dieffenbachii Gray and 839 A. australis (both belonging to the Oceanic group) collected from different localities of New Zealand. This implies that no host switch had occurred within the Oceanic and Atlantic group. If this is the case, infection of A. australis with $P$. rohdei on the Australian mainland and P. mundayi in Tasmania, may have been the result of a host shift of these monogeneans from $A$. reinhardtii to $A$. australis, both eels showing overlapping distributions. Indeed, such shifts have occurred frequently, like that of $P$. bini and $P$. anguillae from $A$. japonica to $A$. anguilla, $A$. rostrata and $A$. marmorata. From these, the third hypothesis may seem most plausible. Based on this hypothesis, ancestral pseudodactylogyrids may have switched to ancestral Indo-Pacific eels, which later dispersed to the North Pacific and evolving to A. japonica, and to the tropical Pacific and evolving to $A$. reinhardtii (see Aoyama et al. 2001). Anguilla reinhardtii and $A$. japonica diverged at an early time within the Indo-Pacific group (Aoyama et al. 2001), and consequently, undiscovered Pseudodactylogyrus species might infect other eels of the Indo-Pacific group and be distributed through tropical regions, where no information about the parasite fauna of anguillid eels has yet been reported. Further studies of other eel species in different localities are required to better understand the co-evolution of anguillid eels and pseudodactylogyrids.

Acknowledgements. We thank David I. Gibson, Natural History Museum, London, Clive R. Kennedy, University of Exeter, UK and Pavel Gerasev, Zoological Institute, St. Petersburg, Russia for their efforts to search for the Pseudodactylogyrus specimens used in Kennedy (1998) and Gusev (1965). Thanks are also due to Tingbao Yang, Sun Yat-sen University, Guangzhou, China for sending us copies of Chinese references unavailable in Japan. 


\section{REFERENCES}

Aоyama J. 2009: Life history and evolution of migration in catadromous eels (genus Anguilla). Aqua-Biosci. Monogr. 2: 1-42.

Aoyama J., Nishida M., Tsukamoto K. 2001: Molecular phylogeny and evolution of the freshwater eel, genus Anguilla. Mol. Phyl. Evol. 20: 450-459.

Castresana J. 2000: Selection of conserved blocks from multiple alignments for their use in phylogenetic analysis. Mol. Biol. Evol. 17: 540-552.

Christison K.W., Baker G.C. 2007: First record of Pseudodactylogyrus anguillae (Yin and Sproston, 1948) (Monogenea) from South Africa. Afr. Zool. 42: 279-285.

Cone D.K., Marcogliese D.J. 1995: Pseudodactylogyrus anguillae on Anguilla rostrata in Nova Scotia: an endemic or an introduction? J. Fish Biol. 47: 177-178.

Froese R., Pauly D. (Eds.) 2015: FishBase. World Wide Web electronic publication, www.fishbase.org, 02/2015.

Golovin P.P. 1977: [Monogeneans of eel during its culture using heated water. In: Investigation of Monogenoidea in U.S.S.R.] Zoological Institute, U.S.S.R. Academy of Sciences, Leningrad, pp. 144-150. (In Russian.)

Gusev A.V. 1965: [A new genus of monogenetic trematodes from Anguilla spp.] Trudy Zool. Inst. Akad. Nauk SSSR, 35: 119-125. (In Russian.)

Hay ward C.J., Iwashita M. Crane J., Ogawa K. 2001: First report of the invasive eel pest, Pseudodactylogyrus bini, in North America and in wild American eels. Dis. Aquat. Org. 44: 53-60.

HiNe P.M. 1978: Distribution of some parasites of freshwater eels in New Zealand. N. Z. J. Mar. Freshw. Res. 12: 179-187.

Iwashita M., Hirata J., Ogawa K. 2002: Pseudodactylogyrus kamegaii sp. n. (Monogenea: Pseudodactylogyridae) from wild Japanese eel Anguilla japonica. Parasitol. Int. 51: 337-342.

Katahira H., Mizuno K., Umino T., Nagasawa K. 2012: Influence of host habitat on the occurrence of gill monogeneans Pseudodactylogyrus spp. on wild Japanese eels Anguilla japoni$c a$. Dis. Aquat. Org. 100: 43-49.

Katahira H., Nagasawa K. 2014: Helminths from the giant mottled eel Anguilla marmorata Quoy and Gaimard in Japan, with a description of Acanthocephalus longiacanthus n. sp. (Acanthocephala: Echinorhynchidae). Syst. Parasitol. 88: 91-102.

Katoh K., Standley D.M. 2013: MAFFT multiple sequence alignment software Version 7: Improvements in performance and usability. Mol. Biol. Evol. 30: 772-780.

KenNedy C.R. 1998: Richness and diversity of macroparasite communities in tropical eels Anguilla reinhardtii in Queensland, Australia. Parasitology 111: 233-245.

KiKUCHI H. 1929: Two new species of Japanese trematodes belonging to Gyrodactylidae. Annot. Zool. Jap. 12: 175-186.
LI, H. 2004: [Description of one new species and one new record of Pseudodactylogyroides of fishes from Guangzhou.] Acta Zootax. Sin. 29: 234-238. (In Chinese.)

Lim, L.H.S. 1995: Two new species of Pseudodactylogyroides Ogawa 1986 (Monogenea) from two species of eleotridid fishes of Peninsular Malaysia. Syst. Parasitol. 31: 25-32.

Ling M.E. 1973: [An Illustrated Book on Fish Disease Pathogens in Hupei Province.] Institute of Hydrobiology, Hupei Province, China, Scientific Press Co., Beijing, China, 456 pp. (In Chinese.)

Minegishi Y., Aoyama J., Inoue J.G., Miya M., Nishida M., Tsuкамото K. 2005: Molecular phylogeny and evolution of the freshwater eels genus Anguilla based on the whole mitochondrial genome sequences. Mol. Phylogen. Evol. 34: 134-146.

Ogawa K. 1984: Pseudodactylogyrus haze sp. n., a gill monogenean from the Japanese goby, Acanthogobius flavimanus. Jpn. J. Parasitol. 33: 403-405.

Ogawa K. 1986: Pseudodactylogyroides gen. n. (Monogenea: Ancyrocephalidae, Pseudodactylogyrinae subf. n.), with a redescription of P. apogonis (Yamaguti, 1940) comb. n. Zool. Sci. 3: 181-185.

OGawa K., Egusa S. 1976: Studies on eel pseudodactylogyrosis-I. Morphology and classification of three eel dactylogyrids with a proposal a new species, Pseudodactylogyrus microrchis. Bull. Jpn. Soc. Sci. Fish. 42: 395-404.

Ogawa K., Ishimaru K., Shirakashi S., Takami I., Grabner D. 2012: Cardicola opisthorchis n. sp. (Trematoda: Aporocolidae) from Pacific bluefin tuna Thunnus orientalis (Temminck and Schlegel, 1844) cultured in Japan. Parasitol. Int. 60: 307-312.

Sasal P., Taraschewski H., Valade P., Grondin H., WielGoss S., Moravec F. 2008: Parasite communities in eels of the Island of Reunion (Indian Ocean): a lesson in parasite introduction. Parasitol. Res. 102: 1343-1350.

Tamura K., Stecher G., Peterson D., Filipski A., Kumar S. 2013: MEGA6: Molecular Evolutionary Genetics Analysis. Version 6.0. Mol. Biol. Evol. 30: 2725-2729.

Tatsukawa K. 2003: Eel resources in East Asia. In: K. Aida, K. Tsukamoto and K. Yamauchi (Eds.), Eel Biology. Springer-Verlag, Tokyo, pp. 293-298.

Wu B., Wang Z., Jiang N. 1988: [A new species of parasitic Monogenea of freshwater fishes from Zhejiang Province.] J. Zhejiang Univ. (Sciences Edition) 15: 194-195. (In Chinese.)

Yin W.-Y., Sproston N.G. 1948: Studies on the monogenetic trematodes of China. Sinensia 19: 57-85.

ZHANG J. 1981: [Thirty-five species of monogenetic trematodes from freshwater fishes in China.] J. South China Normal Univ.. Nat. (Sciences Edition): 62-75. (In Chinese.) 